\title{
Off-Balance Sheet Exposure - Performance Analysis and Risk Measurement of Indian Banks
}

\author{
Appala Raju Middi \\ Christ University. India
}

\begin{abstract}
Banking Sector has under gone enormous changes over the decades initially from ownership to government ownership and open to competition from private and foreign banks after the liberalization of the economy in 1991. Under the regulated economic system, banks used to enjoy complete protection from the government and insulated totally from external shocks. The financial sector reforms initiated by the Government brought unforeseen changes in the general functioning of the banks; as a result banks are compelled to extend their business activities which they were distancing over the years. The exposure to off banking activities to like foreign exchange contracts has led the banks to expose to greater risks but with incremental revenues in the form of other incomes. It is necessary banks to manage the risk through the exposure to various off balance sheet activities.
\end{abstract}

Key words: Government ownership; Liberalisation; regulated economy; off-balance sheet activity; Open Competition; Incremental Revenues ; Risk Exposure

\section{INTRODUCTION}

Banking Sector has traditionally remains a protected industry in many emerging nations including India. Banking had been under insulation cover over the decades with the protection and insulation given by the Government in the different functional activities of the banks. It was fully a regulated environment both for interest charges on deposits and lending activities of the banks, directed lending to institutions were the features of the Indian Banking System. Banking Sector had not experienced any competition from within the country and from outside in a regulated regime. In a protected environment there was a very limited pressure on banks and has resulted in lackluster and inefficiency in banks functioning.

After the liberalization of Indian economy in 1991, a number of radical developments have taken place in the banking sector which has a significant impact on the functioning and development of the banking system. Many of the developments are in the context and consequence of financial sector reforms - like monetary and credit policy, prudential guidelines, development of markets like Government Securities Market. With the opening of the economy in general and banking sector in particular, there was an onslaught of competition in the form of entry of foreign banks, new banks under private sector, there is metamorphic change in the functioning of Banks. To get wider acceptance both at national and international levels prudential norms and guidelines have been made to introduce greater transparency in the functioning of the banking system.

\section{OBJECTIVES OF THE STUDY}

- To understand the changing pattern in Off Balance sheet exposure of commercial banks

- To measure the changes in assets pattern of commercial banks

- To measure the changes in other income levels pattern of commercial banks 
- To measure the impact of OBS exposure on the return and risk of commercial banks

\section{METHODOLOGY}

Secondary data collected from the RBI Publications about OBS exposure of Commercial banks, the assets pattern and changes in the other income levels. Data analysis is done using panel data regression method.

\section{LITERATURE REVIEW}

Off Balance Sheet activities- impact on commercial bank performance, an emerging market perspective by Bora Aktan, Sok-Geechan, Sasa Zichovic, Pinar Evrim - Mandaci 1examines the effect of OBS activities on performance of the banks listed in Istanbul Stock exchange (ISE). Four measures of performance including banks risk exposure, profitability, leverage and liquidity position found both bank specific risk and foreign exchange rate risk are positively related with OBS activities. The result also indicate that OBS activities, due to its hedging perception, improve bank stock returns but have a negative impact on return on equity. Bank risk exposure, Bank failure and Off Balance Sheet activities: An empirical analysis for US commercial banks2, the study investigates the extent to which commercial US banks engage in Off Balance Sheet activities and the possible implication of such engagement on bank risk exposure and bank failure. He differentiated credit substitute, derivative and credit derivative contracts to study the alternative role of bank riskiness. Risk and profitability in Middle East and North Africa Banking System - an examination of the Off Balance Sheet activities by Ahmad Y. Khasawneh and Husam Aldeen Al-Khadash3. The study analyses the role of Off Balance Sheet activities on banks profitability and risk in the Middle East and North Africa Banking System. This study covers period from 2006/2007 financial crises. The result indicates that Off Balance Sheet activities are risk reducing as well as profit generates in Middle East and North Africa Banks. The result also indicates the effect of Off Balance Sheet activities on banks profitability is higher in case of banks located in oil producing countries. This paper derives several LaGrange multiplier test for Panel regression Model with Spatial Error Correlation. This idea is to allow for both with Spatial Error Correlation as well as random region effects in the panel data regression and to test for their joint significance on the risk and profitability of commercial banks. 'Evaluating Off Balance Sheet exposures in Banking crises Determination Models' R.Barrel, E P Davis, D Karim ,Laidze ; NIESR and Bounel University1 studies the impact of Off Balance Sheet exposures on the probability of banking crises in OECD countries since 1980. Variable capturing Off Balance Sheet activity have neglected in most early warning models to date. This is an estimate of Off Balance Sheet exposures of banks by employing the ratio of off- to on Balance Sheet activities in econometric models of crises determination. IMF Working Paper (2000) Research Department Pbreuer2 opined that the simultaneous unwinding if leveraged positions can trigger financial turbulence. Although Balance Sheet measures of leverage are available, it is useful to construct a measure of leverage that incorporates both on and off balance sheet activities. This paper provides measures of leverage implicit in derivative contracts by decomposing the contracts into cash market equivalent components. This interaction between leverage and risk is discussed, and a modified capital adequacy ratio, is calculated which captures Off Balance Sheet exposure. This paper presents a method of measuring the degree of leverage implicit in selective derivative contracts by decomposing the contract and mapping the replicating portfolio into equity and debt components. The effect of off balance sheet financing on profitability and leverage ratios by Saied Jabbarzadeh Kangerluei3, Department of Accounting, Islamic Azad University, Iran, Rahim Mohammad and Sharifi (2012). The effect of off balance sheet financing on firms profitability and leverage ratios before and after off balance sheet financing are compared and also the effect on firms with and without off balance sheet financing are compared 


\section{Financial Sector Reforms}

The process of financial sector reforms introduced in 1991 has been pursued further to strengthen the banks, to infuse competitiveness, to improve operational efficiency and transparency of the financial sector. The financial reforms touched a number of areas Monetary and Credit Policy issues; Reserve ;requirements; interest rates; refinancing facilities; debt restructuring ; indirect monetary control via., securities market ; matters relating to strengthening and consolidation of banks; capital adequacy norms; prudential norms regarding asset classification; income recognition; provisioning for n-non-performing assets; capital to risk weighted adjusted system and the establishment of a strong supervisory system. All the measures stated above are expected to bring efficiency in the functioning of banking system to make the system more vibrant in order to confine the banking system to the international standards.

\section{Perspectives of Banking Sector}

Through the process of correcting exogenous and structural factors bearing upon the banking sector, the highly regulated character of the financial markets was transformed into one characterized by openness, competition, prudential and supervisory discipline. Commercial Banks have entered into a challenging environment and have been redefining their position in tune with the developments in domestic and international markets. Banking Sector have been introducing new products and services, developing new products and services and new methods of doing business as per the expectations of the customers. There is a lot of pressure on the banks to provide better services to the customers, better returns on the savings of the investors and competitive lending practices. There has been a complete transformation from regulated oriented environment to commercial oriented environment. The viability and sustainability of every bank depend on the level to which each bank is able to raise its standards of efficiency and productivity, strategies to expose new lines of business in order to raise additional revenues, improve income to cost ratio and overall operational effectiveness.

In order to respond and withstand the competitive pressures banks are compelled to get into non-traditional activities to generate additional revenues. These non-traditional banking activities are associated with high levels of risk because of any adverse economic conditions and developments in domestic and international markets. Due to competitive pressures, it has become necessary for banks to get into new lines of business activities and as a result banking operations worldwide have undergone phenomenal expansion in the last two decades. Financial liberalization and technical change have created new and complex products and have increased turnover. Shift to new lines of non-traditional banking activities have also created more risks .The growing globalization of banks and the introduction of modern information technology of international banks have enabled banks to rapidly expand their non-fund and off-balance sheet activities. The focus of the banks is to increase the revenues through these kinds of non-conventional activities. Indeed, there has been significant increase in the revenues of the banks with non-fund based transactions but at the same time there is greater exposure to risk because of these transactions in the event of adverse developments in the national and international markets.

The recent global financial crisis is a testimony for the contribution of Off-balance sheet operations of the banking system and the financial crisis got much aggravated because of foreign banks high exposure to these non-fund based operations. The central banks of the respective countries have imposed high restrictions on the exposure of banks for non- fund based operations, because financial crisis may collapse the entire system if not controlled in a decisive way. The OBS exposure by the scheduled Commercial Banks i.e. Public Sector Banks, Private Banks and Foreign Banks in a big way adds to the existing income levels in the form of 
other income in a significant way, but the risk it causes to the soundness of the financial system may be disastrous, if not handled properly. The risk could be in the form of Credit Risk, Liquidity Risk, asset Liability mismatch, Capital Inadequacy, Increase in NPAs etc. and a combination of multiple risks may even lead to systemic risk. Exposure to OBS operations and its default increase the proportions of credit risk and associated increase in NPAs and cause a lot of stress to assets and liabilities management as the short term deposits may have to be diverted for meeting the obligations which were contingent in nature before the default occurred. The higher the credit risk, higher the stressed and higher is the capital adequacy requirements. As the default in credit guarantees occur abruptly due to adverse developments which are unanticipated, it will have the issue of contagion risk effect.

In the event of default by the parties with respect to contingent liability, there will be lot of obligations of cash from the banks which will definitely precipitate financial instability if liquidity problem is not addressed properly. The financial crisis witnessed in 2008 is a clear testimony for this. In such a volatile situation, the importance of monitoring liquidity risk is likely to be greater. The incidents of Northern Rock, Bear Stearns, Lehman Brothers, AIG and Washington Mutual fund are testimony for the liquidity crisis mainly due to exposure in the form Off-Balance sheet activities.

Exposure to Off-Balance Sheet activities is of great concern as its impact on the soundness of the banking system is difficult to assess and measure since there is a lot of uncertainty involved in the OBS activities. In the event of default it will have a severe impact on the entire banking and financial system as witnessed in the severe financial crisis that took place in 2008. During the last ten years there has been a significant increase in the OBs activities of commercial banks more by new private and foreign banks. During the period of high economic growth from 2002 to 2008, there is also a high increase in the OBS exposure as there has been high need for credit in the domestic and international markets to take advantage of favorable business conditions and business cycles.

As the business has become global, the uncertainties have begun to be more due to fluctuations in the exchange rates and high interest rates in the domestic markets. There is a great demand for forward exchange contracts and derivatives trading in international business activities. As economy grows naturally there is growth in business activities both within and outside and this demand more such risk management services. There is great addition to the total income of the banking entities in the form of fees which is considered as 'other income'. Over the years the contribution of income to the total income of the bank entities is quite significant. Banking entities with high risk appetite prepared to assume more of off-balance sheet exposures.

The role of OBS in generating other income is examined by using panel data regression analysis.

This analysis is done for different bank group levels. The data is collected and pooled from the various issues of RBI Report on Trend and Progress of Banking in India.

The log of other income is taken as dependent variable and the independent variables are offbalance sheet assets and the first lag of other incomes. Thus, the model used in the study can be written as: 
Impact of OBS on other income

Sample Period: 2000 to2011 across five different bank groups

No. of pooled observations - 50

Dependent Variable 'Other Income'

\begin{tabular}{lcc}
\hline Explanatory & Coefficients & T-value \\
\hline Intercept & -1.188 & $-1.750^{*}$ \\
Balance sheet Assets & 0.365 & $-3.715^{* * *}$ \\
Off-Balance Sheet Exposures & 0.085 & $2.189^{* *}$ \\
First Lag of Other Income & 0.480 & $4.172^{* * * *}$ \\
\hline
\end{tabular}

R-Squared: 0.89

Adjusted R-Squared: 0.88

DW Statistic: 1.44

Results indicated that one per cent increase in off-balance sheet exposures increase 'other income' of the banking sector by 0.08 per cent. Due to this significant influence on the other income banks have a tendency to expose for off-balance sheet assets in the interest of having more to the revenues of the business in the form of other income. The Off balance sheet assets of the banks in the form of Foreign Exchange Contracts, Guarantees and Acceptances, Interest Rate Swaps and other derivatives are as given. Off Balance Sheet Assets of State Bank Groups from Rs. 97,452 crores in 1999-2000 to Rs. 8,63,415 crores (886 per cent): Nationalised Banks from Rs.1,36,643 crores to Rs.13,26,248 crores(970 per cent) :whole Public Sector Banks from Rs.2,74,095 crores to Rs. Rs.21,89,664 crores(799 per cent): New Private sector Banks from Rs.46,726 crores to Rs.22,08,583 crores(4,727 per cent): Old Private Sector Banks from Rs. 20,115 crores to Rs.1,39,136 crores (691 per cent): foreign Banks from Rs.2,82,252 crores to Rs.93,01,006 crores(3,296 per cent); and All scheduled Commercial Banks from rs.5,84,288 crores to Rs.1,38,38,389 crores(2,368 per cent).

\section{CONCLUSION}

The exposure to Off-Balance sheet activities has gone such phenomenal levels where the size of the total off balance sheet exposures of the Indian banking sector was larger than the total balance sheet assets of the banking sector. The risk associated with this exposure is very high and any default will definitely affect the entire banking sector especially those of the new private banks and foreign banks and lead to systemic risk.

\section{References}

Asset Liability Management. (2014). Retrieved from www.iimb.ernet.in/ vaidya/Asset-liability.pdf Asset Liability Management. (2014). Retrieved from www.allbankingsolutions.com/Banking-Tutor/ALM.shtml Axis Bank. (2014). Retrieved from www.axisbank.com

Bank of Baroda. (2014). Retrieved from www.bankofbaroda.co.in

Brenda wells, K. E. (2009). Asset-Liability Management Problems in the Life Insurance Industry: Lessons from the Past. Journal of Insurance Regulation.

Charumathi, D. B. (2008). Asset Liability Management with special Reference to Interest Rate risk Management in ICICI Bank. WCE London, U.K.

Dash, M. (2013). A study of the impact of Asset-Liability Management on the profitability of Banks in India, Journal of Management Research.

Dr.N.Kavitha. (2012).An assessment - Asset and Liability Management of Scheduled Commercial Banks in India, IJMT, Volume II Issue 4.

Enzo Scannella, D. B. (2013). Interest Rate Risk in Banking: a Theoretical and Empirical Investigation through a Systemic Approach (Asset \& Liability Management). Business System Review, Volume II - Issue 1. 
HDFC. (2014). Retrieved from www.hdfcbank.com

Icici bank. (2014). Retrieved from www.icicibank.com

Investopedia. (2014). Retrieved from www.investopedia.com/terms/a/asset-liabilitymanagement.

Mihir Dash, K. V. (2012).An analysis of Asset-Liability Management, Journal of Management Research .

Mohammad Omar Faruk (Corresponding Author), R. A. (2014). Asset Liability Management of a Commercial BankA Study on Prime Bank. International Journal of Information, Business and Management, , Vol. 6, No.1, .

Mohapatra, S. C. (2009). An Empirical Study of Asset Liability Approach of Indian Banks. Indiana University of Pennsylvania.

Money Control. (2014). Retrieved from www.moneycontrol.com

Pathak, M. D. (2009). A linear programming model for assessing Asset-Liability management in Banks Journal of Management Research, Volume 2.

Pathak, M. D. (2009). Canonical Corrleation analysis of Asset-Liability management in Banks. Journal of Management Research.

Punjab National Bank. (2014). Retrieved from www.pnbindia.in

Reserve Bank of India. (2014). Retrieved from www.rbi.org.in

Robert Ferstla, A. (2010). Asset-liability management under time-varying investment opportunities. Journal of Finance.

Singh, P. (. (2013). Asset-Liability management in Banks - Adynamic approach, AIMA Journal of Management Research.

Spyridon D Vrontos, I. D. (2009). Asset-Liability Management for Pension Funds in a Time-Varying Volatility Environment. Journal of Management Research.

State Bank of India. (2014). Retrieved from www.sbi.co.in

Vij, M. (2001). Asset Liability Management in Banks and Financial Institution- A case Study on IDBI. Journal of Management Research, Volume 1, Number 2.

Xi Yang, J. G. (2011). Asset liability management modelling with risk control by stochastic dominance. Journal of Asset Management, Vol. 11, 2/3, 73-93. 